\title{
Profil Penalaran Kuantitatif Siswa SMP Ditinjau dari Gender
}

\author{
Dzikra Fu'adiah \\ STAI Siliwangi \\ e-mail: dzikra.fuadiah@gmail.com
}

\begin{abstract}
ABSTRAK
Penelitian kualitatif deskriptif ini bertujuan untuk mendeskripsikan profil penalaran kuantitatif siswa SMP ditinjau dari gender. Untuk mencapai tujuan tersebut, digunakan tiga instrumen, yaitu tes kemampuan matematika untuk menentukan subjek penelitian dan tugas penalaran kuantitatif dan pedoman wawancara untuk mengumpulkan data profil penalaran kuantitatif subjek penelitian. Profil penalaran kuantitatif ditinjau dari gender adalah sebagai berikut: (1) subjek perempuan dan subjek lakilaki memahami informasi kuantitatif dengan berbagai bentuk; (2) subjek laki-laki merumuskan persamaan dari hasil interpretasi informasi kuantitatif yang diberikan secara implisit; (3) dari hasil interpretasi, subjek perempuan menyebutkan terdapat dua kuantitas sedangkan subjek laki-laki menyebutkan terdapat tiga kuantitas yang terlibat dalam masalah soal dan keduanya menyebutkan beberapa hubungan kuantitas-kuantitas tersebut; (4) subjek perempuan menggunakan metode geometri dengan menerapkan suatu sifat, sedangkan laki-laki menggunakan metode aljabar dengan menyusun dan menyelesaikan suatu persamaan; (5) keduanya memperkirakan jawaban dan memeriksa kemasukakalannya dengan berbeda sesuai dengan metode yang digunakan; (6) keduanya mengkomunikasikan informasi kuantitatif secara lisan maupun tulisan; (7) kedua subjek mengenali keterbatasan metode yang digunakan dalam menyelesaikan soal.
\end{abstract}

Kata kunci: Penalaran Kuantitatif, Gender

\begin{abstract}
This research was a descriptive qualitative reseach. The research objectives were to describe profile of the quantitative reasoning of female and male junior high school students. To reach this objective, the reseacher employed three instruments, namely a mathematical ability test to determine participants and quantitative reasoning tasks and a interview guidance to collect data of profile of the quantitative reasoning of the students. Profile of the quantitative reasoning based on gender were: (1) the both of participants understand quantitative information given in various formats; (2) the male participant can formulate an equation as a product of interpreating quantitative information which given implicitly; (3) as a result of interpratation, the female participant said that there were two quantities, whereas the male participant said there were three quantities involved in a problem and both of them mentioned several relationships among the quantities; (4) the female employed the geometry method by applying the properties of parallel lines and a two-line intersection, whereas the male employed algebra method by formulating and solving an one-variable linear equation to solve a problem; (5) both of them estimated answers and checked its reasonableness in different ways appropriate to the method that each employed; (6) both of them communicated quantitative information in verbal and written ways; (7) both of participants recognised a limitation of each own method that they umployed to solve a problem.
\end{abstract}

Keywords: Quantitative Reasoning, Gender

\section{PENDAHULUAN}

Penalaran merupakan salah satu aspek dalam tujuan pengajaran matematika SMP. Dalam Peraturan Menteri Pendidikan Nasional (Permendiknas) No.22 tahun 2006 (Depdiknas, 2006) menyatakan salah satu tujuan mata pelajaran matematika SMP agar peserta didik memiliki kemampuan menggunakan penalaran pada pola dan sifat, melakukan manipulasi matematika dalam membuat generalisasi, menyusun bukti, atau menjelaskan gagasan dan pernyataan matematika. Sehingga, Matematika berperan untuk melatih siswa bernalar dalam menarik kesimpulan untuk memecahkan masalah, baik 
masalah dalam matematika maupun masalah dalam kehidupan sehari-hari.

Terdapat masalah yang berkaitan dengan kuantitas yang ditemui oleh setiap orang setiap harinya. Kuantitas adalah kualitas sesuatu yang terbentuk dari proses pengukuran. Pengertian tersebut sesuai dengan pengertian yang diberikan Thompson (1990), yaitu " $A$ quantitty is a quality of something that one has conceived as admitting some measurement process". Panjang, luas, kecepatan dan volume merupakan beberapa atribut yang dapat diukur kuantitasnya (Ellis, 2011: 216). Satu kuantitas dapat berhubungan dengan kuantitas lain, contohnya kecepatan adalah kuantitas yang berhubungan dengan kuantitas jarak dan waktu. Ketika siswa melibatkan penalaran kuantitatif, siswa berkerja dengan kuantitaskuantitas dan hubungan-hubungan kuantitas tersebut (Ellis, 2011: 216). Contohnya, seorang siswa mungkin membandingkan kuantitas-kuantitas secara aditif, dengan membandingkan seberapa lebih tinggi seseorang dengan orang lain, atau secara multiplikatif, dengan menentukan berapa kali lebih besar satu objek terhadap objek lain (Ellis, 2011: 216). Informasi yang memuat informasi berupa kuantitas dan hubungan satu kuantitas dengan kuantitats lain disebut sebagai informasi kuantitatif.

Dari sisi pendidik dan guru, tujuan utama matematika di seluruh dunia adalah menghubungkan antara pikiran siswa dan masalah sehari-hari yang dapat diselesaikan secara matematis (Karim, 2007). Tujuan ini dapat dicapai dengan memperbaiki sikap siswa terhadap matematika. Perbaikan tersebut, menurut Karim (2007), akan terjadi jika siswa dapat menggunakan penalaran kuantitatif. Berdasarkan hasil penelitian Karim (2007), penggunaan penalaran kuantitatif akan meningkatkan tingkat kemampuan siswa dalam memahami dan menyelesaikan masalah sehari-hari, number senseatau tingkat penguasaan bilangan, perhitungan mental atau perhitungan tanpa menggunakan suatu alat selain otak manusia, dan menilai solusi dari suatu masalah.

Penalaran kuantitatif seharusnya tidak hanya diterapkan dalam proses pembelajaran pada tingkat pendidikan tinggi tetapi juga pada tingkat pendidikan dasar, misalnya pada tingkat SMP (Madison, 2003: 7). Hal ini senada dengan pernyataan Ancker dan Abramson, 2012; Cavanaugh dkk, 2008; Master dkk, 2010; Nelson dkk, 2008; dan William dkk, 1995 (NICHE (Numeracy Infusion Course for Higher Education), 2015) yang menyatakan bahwa kemampuan penalaran kuantitatif yang buruk akan berdampak serius secara sosial dan ekonomi. Mulai dari menimbulkan kesalahan dalam pengambilan keputusan sampai kesalahan medis yang dilakukan pasien maupun profesional kesehatan. Penalaran kuantitatif akan dapat membuat siswa memahami dan membuat argumen-argumen mutakhir yang didukung oleh fakta-fakta kuantitatif dan dapat mengkomunikasikan secara jelas argumen tersebut dalam berbagai representasi, seperti: menggunakan kata-kata, tabel, grafik, dan rumus. Oleh karena itu, dampak penalaran kuantitatif tidak terbatas pada kemampuan yang diperoleh dalam mata pelajaran matematika, tetapi mencakup kemampuan untuk menyelesaikan masalah dalam konteks sehari-hari dan berbagai profesi.

Lebih fokus, Smith dan Thompson (2011), yang memiliki perhatian sangat besar terhadap penalaran kuantitatif untuk mengembangkan penalaran aljabar siswa SMP, menyarankan penalaran kuantitatif sebagai akar untuk mengembangkan penalaran aljabar. Smith dan Thompson (2011) berpendapat pengembangan ini tidak mudah dan tidak cepat untuk dilakukan. Siswa yang cakap menghasilkan penyelesaian dari berbagai pengalaman selama bertahun-tahun akan lebih sukses dalam aljabar karena membuat pengetahuan aritmetika dan aljabar lebih bermakna dan produktif. Koedinger dan Nathan (2004: 129) menyatakan jika siswa kelas VII dan VIII SMP melibatkan penalaran kuantitatif dalam merepresentasikan suatu masalah, maka terdapat perubahan positif representasi masalah dari segi kinerja dan proses kognitif siswa dalam aljabar. Kedua pernyataan tersebut mengungkapkan penalaran kuantitatif menjadi dasar untuk pengembangan diri siswa SMP dalam mempelajari topik bahasan matematika yang lebih lanjut dan meningkatkan kemampuan siswa merepresentasikan masalah dari segi keterampilan dan proses kognitif. 
Untuk mengembangakan penalaran kuantitatif pada suatu pembelajaran, tentu diperlukan analisis yang menyuluruh dan dalam tentang karakteristik siswa. Sehingga, dapat menghasilkan keputusan-keputusan yang tepat dalam pengembangan pembelajaran yang berkaitan dengan penalaran kuantiitatif. Salah satu analisis karakteristik siswa tersebut adalah tentang profil penalaran kuantitatif siswa.

PISA (Programme for International Student Assesment) merupakan studi internasional yang mengukur kemampuan siswa SMP. Salah satu konten matematika dalam studi PISA adalah quantity. Konten quantity ini mengukur kemampuan siswa dalam bernalar secara kuantitatif (Hayat dan Yusuf, 2010). Hasil studi PISA pada tahun 2012 (Firman, 2014) menunjukkan hanya $50.25 \%$ siswa Indonesia yang mampu menyelesaikan masalah kuantitas sederhana dan kebanyakan siswa Indonesia tidak mampu menyelesaikan masalah kuantitas yang lebih kompleks. Oleh karena itu, peneliti tertarik untuk mengetahui deskripsi profil penalaran kuantitatif siswa SMP di Indonesia, yaitu bagaimana cara siswa menalar infomasiinformasi kuantitatif untuk menyelesaikan suatu masalah.

Salah satu faktor yang perlu diperhatikan dalam mempelajari matematika adalah faktor gender. Gender diperkirakan mempengaruhi kemampuan matematika. Menurut Ceci dan Williams, 2006; Park dkk, 2007; dan Wai dkk, 2007 (Lakin, 2013), pengaruh gender terhadap kemampuan kognitif telah lama menjadi sumber perdebatan tajam dan perhatian di antara para peneliti. Hal ini terjadi karena implikasi gender terhadap pekerjaan yang berkaitan erat dengan matematika dan terhadap relevansi profil pribadi dasar seseorang. Pernyataan tersebut sejalan dengan hasil penelitian Benbow, Lubinski, Shea, Eftekhari-Sanjani (2000) yang menyatakan bahwa terdapat perbedaan kemampuan penalaran matematika antara laki-laki dan perempuan. Hopkins (Pai'pinan, 2013) mengemukakan bahwa beberapa hasil penelitian menunjukkan laki-laki cenderung lebih unggul dalam prestasi matematika. Lakilaki memiliki skor yang lebih tinggi pada tes konsep matematika, pemecahan masalah dan matematika lanjutan. Kartono (Hidayati, 2013) menyatakan bahwa betapapun baik dan cemerlangnya intelegensi seorang perempuan, namun hampir tidak mempunyai ketertarikan yang menyeluruh pada soal-soal teoritis dibandingkan dengan laki-laki. Jadi perempuan pada umumnya lebih tertarik pada hal-hal yang praktis.

Lebih khusus, gender juga mempengaruhi kemampuan penalaran kuantitatif. Stafford (1971) menemukan terdapat hubungan positif signifikan antara gender dan kemampuan penalaran kuantitatif. Dengan demikian, antara gender dan kemampuan kognitif, khusunya kemampuan penalaran kuantitatif, terdapat hubungan yang signifikan. Hasil penelitian yang menunjukkan rasio perbedaan tingkat kemampuan penalaran kuantitatif antara siswa laki-laki dan siswa perempuan telah dilakukan oleh beberapa peneliti. Penelitian-penelitian tersebut menunjukkan perbedaan yang cukup signifikan. Siswa laki-laki pada umumnya memiliki kemampuan lebih unggul dalam penalaran kuantitatif (Tiang dan Huang, 2009, Lakin, 2013, dan Wang, 2006).

Sudarman (2009) menyatakan bahwa dengan mengetahui proses penalaran siswa, guru dapat melacak letak dan jenis kesalahan yang dilakukan siswa. Dengan mengetahui proses berpikir siswa, guru dapat mengetahui kesalahan berpikir yang terjadi. Informasi tentang deskripsi profil penalaran kuantitatif siswia SMP laki-laki maupun perempuan dapat digunakan sebagai dasar untuk mempersiapkan pengembangan kemampuan dan keterampilan dalam mempelajari matematika sehingga kemampuan siswa menganalisis dan menyelesaikan masalah dan mengkomunikasikan solusi masalah secara jelas dapat terbentuk dengan baik.

Berdasarkan latar belakang tersebut penelitian ini secara umum bertujuan untuk mendeskripsikan profil penalaran kuantitatif siswa SMP ditinjau dari gender. Secara khusus bertujuan untuk mendeskripsikan profil penalaran kuantitatif siswa SMP perempuan dan siswa SMP laki-laki.

\section{METODE}

Penelitian ini mendapatkan data deskriptif berupa kata-kata tertulis atau lisan dari siswa, hasil kerja siswa dan hasil 
pengamatan perilaku siswa yang dapat diamati.

Siswa SMP kelas VIII yang memiliki kemampuan matematika sedang dipilih sebagai subjek penelitian karena pertimbangan:

1. Usia siswa berkisar antara 12-14 tahun merupakan periode operasional formal awal. Menurut Nur (2001), ini adalah periode awal siswa sadar dan kritis terhadap penalarannya sendiri, menampilkan pemikiran reflektif atas proses pemecahan masalah dan memeriksa kesimpulan-kesimpulan dengan pengecekan sumber-sumber informasi, menggunakan informasi lain yang diketahui atau mencari pemecahan dari suatu sudut pandang lain, dimana kemampuan itu yang dibutuhkan dalam proses penalaran kuantitatif.

2. Berdasarkan hasil penelitian Lobato dan Siebert (2002), hasil wawancara siswa kelas VIII dapat diinvestigasi penalaran kuantitatifnya secara rinci dan siswa dapat mengkonstruksi hubungan ganda antara dua kuantitas.

3. Siswa memiliki tingkat kemampuan matematika sedang. Penelitian ini memilih siswa yang memiliki kemampuan matematika sedang karena menurut Davidson dan McKinney, sedikit orang yang terlatih bekerja dengan konsep matematika yang kompleks, tetapi banyak yang memahami matematika dengan cukup baik untuk mengembangkan opini informatif terhadap konsep kuantitatif. Berdasarkan penyataan tersebut, maka dalam melakukan penalaran kuantitatif tidak membutuhkan kemampuan matematika kompleks yang tinggi.

4. Siswa yang mewakili sebagai subjek laki-laki atau subjek perempuan ditentukan dengan mempertimbangkan peran, kedudukan, dan tugas siswa dilingkungan sekolah. Hal tersebut dipertimbangkan atas dasar hasil wawancara personal terhadap calon subjek dan hasil pengamatan terhadap calon subjek di lingkungan sekolah.
5. Siswa dapat berkomunikasi secara lisan maupun tulisan berdasarkan informasi guru matematika siswa.

Penelitian ini melalui 4 tahap: (1) tahap persiapan yaitu merancang instrument TKM dan TPK, pedoman wawancara, dan lembar validasi; memvalidasi instrumen pendukung penelitian; melakukan uji keterbacaan soalsoal yang terdapat dalam TKM dan TPK; dan melakukan survey ke tempat atau lokasi penelitian; (2) tahap pelaksanaan penelitian, TKM kepada siswa kelas VIII SMP untuk menentukan subjek penelitian. Siswa dikelompokkan sesuai kategori kemampuan matematika siswa (kemampuan matematika sedang). Setelah subjek terpilih, peneliti mengumpulkan data untuk mendeskripsikan penalaran kuantitatif siswa dengan memberikan TPK dan melakukan wawancara berkaitan dengan hasil penyelesaian TPK yang setiap subjek selesaikan. Dari kegiatan tersebut diperoleh data hasil wawancara penyelesaian TPK berupa rekaman audiovisual; (3) tahap analisis data, menganalisis data dan memeriksa kesesuaian data dengan cara triangulasi data wawancara penyelesaian tugas penalaran kuantitatif dan mendeskripsikan hasil analisis data berupa profil penalaran kuantitatif siswa; (4) penulisan laporan hasil penelitian tidak terlepas dari keseluruhan tahapan kegiatan penelitian. Pada tahap pembuatan laporan peneliti menyusun kerangka dan isi laporan, menelaah hasil penelitian, dan menulis laporan.

\section{HASIL DAN PEMBAHASAN Profil Penalaran Kuantitatif Siswa SMP Perempuan.}

Subjek F membutuhkan waktu sekitar 2 menit untuk membaca soal. Walaupun tidak ada konfirmasi berapa kali subjek $F$ membaca soal dari pertama kali mendapatkan soal tersebut, namun subjek F menyatakan sudah selesai membacanya setelah 2 menit mulai membaca soal untuk pertama kali. Sementara hasil observasi kecil yang dilakukan oleh peneliti terhadap waktu yang dibutuhkan untuk membaca 
soal tersebut kepada orang yang pertama kali membaca soal tersebut menunjukkan bahwa untuk membaca soal tersebut hingga pembaca mengetahui cerita soal hanya membutuhkan waktu 1 menit. Subjek F beberapa kali membaca soal untuk memahami informasi yang diberikan dalam bentuk kata-kata yang terdapat pada soal.

Subjek F tidak sampai menyusun atau menyebutkan rumus berupa persamaan yang diberikan secara implisit dalam soal, namun hanya sampai menyimpulkan bahwa nilai kuantitas dari dua subjek masalah sama. Informasi yang disajikan dalam bentuk tabel dapat dibaca oleh subjek $F$. Hal ini terbukti, subjek $\mathrm{F}$ menyebutkan informasi-informasi dari tabel dan menunjuk pada bagian mana informasi tersebut didapat. Sedangkan informasi yang disajikan dalam bentuk grafik, subjek $\mathrm{F}$ menyebutkan sebagai 'diagram'. Informasi dari grafik dapat dibaca oleh subjek F. Hal ini terbukti, subjek $\mathrm{F}$ menyebutkan informasi-informasi dari grafik dan menunjukkan pada bagian mana informasi tersebut didapat. Sehingga, subjek F membaca informasi kuantitatif yang diberikan dalam berbagai bentuk, walaupun subjek $\mathrm{F}$ tidak menyimpulkan persamaan yang diberikan secara implisit dari hubungan kuantitas-kuantitas dalam soal.

Dalam memahami dan menganalisis informasi kuantitatif, subjek $\mathrm{F}$ dapat menyampaikan kembali hal-hal yang diketahui dari soal dengan kata-kata subjek F sendiri secara lisan maupun tulisan dan memperkirakan jawaban yang akan didapatkan dengan menganalisis grafik yang terdapat pada soal. Subjek F menentukan batasan masalah berdasarkan situasi masalah.

Dalam menginterpretasi kuantitas tertentu yang berhubungan atau berubah atau transformasi menjadi kuantitatas lain, Subjek F menyebutkan (1) kuantitas yang terdapat dalam soal dan diberikan secara eksplisit, yaitu waktu dan jarak pada TPK 1 dan waktu dan penurunan suhupada TPK 2; (2) model operasi kuantitatif, yaitu perbandingan aditif antara dua nilai dalam satu kuantitas, yaitu kuantitas waktu berjalan pada soal TPK 1 dan kuantitas waktu penurunan suhu pada soal TPK 2; (3) hasil perhitungan operasi kuantitatif; (4) perbedaan nilai antara dua kuantitas, yaitu antara kuantitas waktu dan jarak yang ditempuh dari rumah ke sekolah dalam soal TPK 1 dan antara kuantitas waktu dan penurunan suhu dari suhu ruangan ke suhu terendah kulkas dalam soal TPK 2. Subjek $\mathrm{F}$ dapat menyebutkan hubungan antara nilai kuantitas yang diketahui dengan hal yang ditanyakan dalam soal dan menyimpulkan hasil interpretasi nilai-nilai dari kuantitas yang diketahui dengan memperkirakan kemungkinan jawaban bisa didapat atau tidak berdasarkan situasi masalah dalam soal.

Subjek F memecahkan masalah menggunakan metode geometri dan mengetahui bahwa informasi yang disajikan dalam bentuk grafik yang dibutuhkan untuk menyelesaikan soal. Subjek F menggunakan metode geometri dengan memanfaatkan sifat-sifat dalam geometri, yaitu kesejajaran garis dan perpotongan dua garis. Subjek F menyebutkan bahwa titik potong antara dua garis yang mempresentasikan kecepatan subjek masalah (Jodi dan Adik, Kulkas A dan Kulkas B) sebagai titik temu dan dari titik potong tersebut ditentukan jawaban soal. Teknik yang digunakan yaitu penggunaan sifat-sifat dalam geometri, yaitu kesejajaran garis dan titik potong. Teknik tersebut diterapkan oleh subjek perempuan dengan benar. Subjek perempuan tepat menggunakan sifat kesejajaran garis untuk menyesuaikan situasi masalah yang akan diselesaikan dan sifat perpotongan dua garis yang menunjukkan perpotongan dua garis menghasilkan nilai kuantitas yang sama sehingga dapat dimanfaatkan untuk mendapatkan jawaban dari masalah yang memiliki situasi dimana ada dua nilai kuantitas yang sama. Hal ini sejalan dengan pernyataan Krutetskii (1976: 342) bahwa perempuan lebih unggul dalan ketepatan, ketelitian, kecermatan dan keseksamaan berpikir. Subjek perempuan seksama dan cermat dalam menentukan angka yang tepat untuk titik potong hingga didapat jawaban soal. 
Dalam memperkirakan jawaban, subjek $F$ memilih dan menggunakan strategi komputasi yang tepat dan efisien untuk menyelesaikan soal yaitu dengan membagi setiap interval pada sumbu horizontal menjadi beberapa bagian,pada TPK 1 membagi menjadi 5 bagian dan 4 bagian pada TPK 2. Subjek F mengestimasi jawaban yang akan didapatkan dengan memanfaatkan grafik yang diberikan. Sedangkan dalam memeriksa kemasukakalan, subjek menyatakan bahwa perhitungan yang dilakukan hingga didapat jawaban dari soal belum tentu akurat karena estimasi penentuan angka pada grafik belum tentu benar. Tidak terjadi kesalahan dalam proses penalaran yang dilakukan oleh subjek $F$ dalam menyelesaikan soal, namun subjek $F$ memeriksa keakuratan jawaban atau hasil dengan melihat keakuratan dari pembagian interval pada sumbu horizontal dan tidak memeriksa kembali kemasuk-akalan jawaban. Kemudian, subjek F menyimpulkan jawaban soal sesuai dengan konteks permasalahan dalam soal.

Subjek F mengkomunikasikan seluruh informasi kuantitatif dalam proses menyelesaikan soal secara lisan maupun tulisan. Subjek F kurang cakap dalam memilih dan merangkai kata-kata untuk menjawab atau merespon pertanyaan atau perintah peneliti. Beberapa kali subjek $F$ salah memilih kata.

Subjek F memilih kata 'jarak' untuk menyebutkan nilai kuantitas waktu yang diketahui dalam soal. Peneliti beberapa kali mengkonfirmasi kembali apa yang dimaksud dari jawaban dan respon subjek F. Sehingga, peneliti menyimpulkan subjek $\mathrm{F}$ kurang cakap dalam berbahasa. Hal ini bertentangan dengan pernyataan Geary dkk (2000) bahwa anak perempuan lebih unggul dalam bidang bahasa dan menulis daripada anak laki-laki. Subjek F mengkomunikasikan jawaban soal dengan menerjemahkan jawaban soal ke konteks permasalahan dalam soal yang awalnya didapat berupa pernyataan atau representasi matematis.

Dalam mengenali keterbatasan metode matematis, subjek F menyebutkan bahwa cara yang digunakan oleh subjek $\mathrm{F}$ memiliki keterbatasan yaitu tidak terdapat uraian yang rinci tertulis tentang proses penyelesaian, sehingga tidak mudah bagi orang lain untuk mengerti proses penyelesaiannya.

Kartono (Hidayati, 2013) menyatakan bahwa betapapun baik dan cemerlangnya intelegensi seorang perempuan, namun hampir tidak mempunyai ketertarikan yang menyeluruh pada soal-soal teoritis dibandingkan dengan laki-laki. Jadi perempuan pada umumnya lebih tertarik pada hal-hal yang praktis. Pendapat Kartono tersebut berlaku terhadap subjek F. Walaupun subjek $\mathrm{F}$ menginterpretasikan informasi-informasi kuantitatif yang terdapat dalam soal, namun subjek F tidak menggunakannya lebih lanjut untuk menyelesaikan soal. Subjek F lebih memilih menerapkan pengetahuannya tentang sifat-sifat dalam geometri untuk menyelesaikan soal.

\section{Pembahasan Profil Penalaran Kuantitatif Siswa SMP Laki-laki}

Subjek M membutuhkan waktu sekitar 1 menit untuk membaca soal. Walaupun tidak ada konfirmasi berapa kali subjek $\mathbf{M}$ membaca soal dari pertama kali mendapatkan soal tersebut, namun subjek M menyatakan sudah selesai membacanya setelah 1 menit mulai membaca soal untuk pertama kali. Sama halnya dengan hasil observasi kecil yang dilakukan oleh peneliti terhadap waktu yang dibutuhkan untuk membaca soal tersebut kepada orang yang pertama kali membaca soal tersebut menunjukkan bahwa untuk membaca soal tersebut hingga pembaca mengetahui cerita soal membutuhkan waktu 1 menit. Subjek M membutuhkan beberapa kali membaca soal untuk memahami informasi yang diberikan dalam bentuk kata-kata yang terdapat pada soal.

Subjek $M$ menyusun atau menyebutkan rumus yang diberikan secara implisit dalam soal. Rumus tersebut disusun berdasarkan kesimpulan bahwa nilai kuantitas dari dua subjek masalah sama. Subjek M bahkan mengetahui bahwa rumus hubungan antara tiga kuantitas, yaitu 
kuantitas jarak, waktu dan kecepatan berjalan dalam soal TPK 1 dan kuantitas penurunan suhu, waktu dan kecepatan penurunan suhu dalam soal TPK 2 digunakan untuk menyelesaikan soal. Untuk informasi dalam bentuk tabel yang diberikan dalam soal, subjek $M$ mampu membacanya dan menunjuk pada bagian mana informasi tersebut didapat. Informasi yang diberikan dalam bentuk grafik yang subjek M sebut sebagai 'diagram', juga dapat dibaca oleh subjek M. Hal ini dibuktikan subjek $M$ dapat menyebutkan informasi-informasi dari grafik dan menunjukkan pada bagian mana informasi tersebut didapat.

Dalam memahami dan menganalisis informasi kuantitatif, subjek M menyampaikan kembali hal-hal yang diketahui dari soal dengan kata-kata subjek M sendiri secara lisan dan tulisan dalam bentuk kata-kata dan gambar. Subjek M menyatakan situasi yang ditanyakan dalam soal mungkin saja terjadi. Subjek $M$ menentukan batasan masalah dengan menyebutkan hal yang ditanyakan dalam soal.

Dalam menginterpretasi kuantitas yang berhubungan atau berubah atau transformasi menjadi kuantitatas lain, Subjek M menyebutkan kuantitas yang terdapat dalam soal dan diberikan secara eksplisit (waktu dan jarak dalam TPK 1 dan waktu dan penurunan suhu pada TPK 2) maupun implisit (kecepatan berjalan pada TPK 1 dan kecepatan penurunan suhu pada TPK 2),dan menuliskan hubungan antara kuantitas-kuantitas tersebut, yaitu kecepatan berjalan diperoleh dari perbandingan multiplikatif antara jarak dan waktu dari soal TPK 1 dan kecepatan penurunan suhu diperoleh dari perbandingan multiplikatif antara penurunan suhu dan waktu dari soal TPK 2. Kemudian, subjek M menyebutkan model operasi kuantitatif berdasarkan informasi dalam soal, yaitu perbandingan aditif antara dua nilai dalam satu kuantitas, yaitu kuantitas waktu berjalan dan kuantitas kecepatan berjalan pada soal TPK 1 dan kuantitas waktu penurunan suhu dan kuantitas kecepatan penurunan suhu pada soal TPK 2. Dalam penarikan kesimpulan hasil interpretasi, subjek $M$ menyimpulkan bahwa nilai dari suatu kuantitas adalah sama, yaitu jarak yang akan ditempuh Jodi dan adik dari rumah ke posisi Jodi menyusul Adik pada TPK 1 dan penurunan suhu yang terjadi pada kulkas A dan kulkas B dari suhu ruangan ke suhu dimana suhu kulkas A akan mencapai posisi suhu yang sama dengan suhu kulkas B pada TPK 2. Subjek M memisalkan posisi tersebut dengan titik $\mathrm{T}$ dan memperkirakan kemungkinan jawaban berdasarkan situasi masalah dalam soal.

Dalam menyelesaikan soal, subjek $M$ menentukan dan menggunakan metode aljabar dan mengetahui informasi yang dibutuhkan untuk menyelesaikan soal, yaitusuaturumus, pembentukan persamaan, dan hal-hal yang diketahui yang dibutuhkan untuk menyelesaikan. Subjek $M$ bahkan menggambarkan dalam berbagai teknik untuk memecahkan masalah dan menerapkan teknik dengan benar untuk menyelesaikan masalah, yaitu menggunakan rumus kecepatan dalam menyelesaiakan soal, mengillustrasikan situasi masalah dan membuat dan menyelesaikan persamaan yang disusun oleh subjek M sendiri.

Dalam memperkirakan jawaban, Subjek M memilih dan menggunakan strategi komputasi yang tepat dan efisien untuk menyelesaikan soal. Hal ini terlihat dari Subjek M(1)menyusun persamaan yang tersusun atas variabel yang mewakili hal yang ditanyakan dan nilai dari variabel yang nilainya telah diketahui dan yang nilainya harus dicari terlebih dahulu; (2) menggunakan sifat operasi aritmetika, yaitu sifat distributif operasi perkalian terhadap operasi penjumlahan, untuk menyelesaikan persamaan; (3) mengelompokkan suku yang memuat variabel yang ditanyakan ke ruas kiri persamaan dan konstanta ke ruas kanan persamaan, yaitu dengan cara memindahkan lawan dari suku yang memuat variabel tersebut yang berada di ruas kanan ke ruas kiri dan lawan dari konstanta yang berada di ruas kiri ke ruas kanan; (4) mengoperasikan bilangan dengan algoritma yang benar, yaitu Jurnal "Mosharafa", Volume 5, Nomor 2, Mei 2016 ISSN 20864280 
pecahan dengan menentukan KPK dari penyebut kedua koefisien variabel yang nilainya ditanyakan dan setelah itu menjumlahkan pembilang-pembilangnya; (5) mengalikan kedua ruas dengan -1 (negatif satu) dan setelah itu membagi ruas kanan dengan koefisien dari variabel yang nilainya ditanyakan, sehingga didapat nilai dari variabel yang ditanyakan. Subjek M memeriksa tingkat akurasi jawaban yang didapatkan. Hal ini ditunjukkan dengan subjek $M$ menyatakan jawabannya sudah benar karena penyelesaian yang digunakan sudah benar dan memeriksa jawabannya dengan melihat kesesuai jawaban yang didapatkan dengan hal-hal yaang diketahui pada soal dan menyatakan bahwa jawaban tersebut masuk akal. Tidak terjadi kesalahan dalam proses penalaran yang dilakukan oleh subjek $\mathrm{M}$ dalam menggunakan metode aljabar untuk menyelesaikan soal. Kemudian, subjek M menyimpulkan jawaban soal sesuai dengan konteks permasalahan dalam soal.

Subjek M mengkomunikasikan seluruh informasi kuantitatif dalam proses menyelesaikan soal secara lisan maupun tulisan dan kemudian menerjemahkan jawaban soal ke konteks masalah dalam soal yang awalnya didapat berupa penyelesaian persamaan.

Subjek M menyebutkan keterbatasan metode matematis yang digunakan dalam memecahkan masalah yaitu dari simbolsimbol yang digunakan membuat pembaca dan yang melihat hasil kerja subjek $\mathbf{M}$ kebingungan dan ada kemungkinan terjadi kesalahan perhitungan dalam menyelesaikan persamaan.

Subjek M mengumpulkan berbagai informasi kuantitatif yang terdapat pada soal, menginterpretasikannya, memilih pengetahuan subjek $M$ sebelumnya yang bermanfaat untuk menyelsaikan soal, dan menganalisis semua semua masukan tersebut untuk menyusun persamaan linier satu variabel. Subjek M benar-benar menggunakan hasil interpretasi hubungan kuantitatif yang ada dalam soal hingga didapat persamaan linear satu variabel. Ini menunjukkan bahwa proses bernalar dilakukan oleh subjek. Profil subjek M tersebut sejalan dengan pendapat $\mathrm{M}$. Krutetski (1976:342) bahwa laki-laki lebih unggul dalam penalaran, dan memiliki kemampuan matematika dan mekanika yang lebih baik daripada perempuan.

Dari hasil analisis profil penalaran kuantitatif, kedua subjek mampu menyelesaikan soal pada tugas penalaran kuantitatif dengan menggunakan metode matematis yang berbeda. Subjek $M$ menggunakan metode geometri dengan mengaplikasikan sifat-sifat dalam geometri, sedangkan subjek $\mathrm{M}$ menggunakan metode aljabar dengan menyusun persamaan dan menyelesaikannya. Hal tersebut sejalan dengan pendapat Davidson dan McKinney, yang menyatakan bahwa sedikit orang yang terlatih bekerja dengan konsep matematika yang kompleks, tetapi banyak yang memahami matematika dengan cukup baik untuk mengembangkan opini informatif terhadap konsep kuantitatif. Sehingga, untuk melakukan penalaran kuantitatif tidak membutuhkan kemampuan matematika kompleks yang tinggi. Siswa tidak membutuhkan konsep matematika yang kompleks atau tingkat kemampuan matematika yang tinggi dalam menganalisis, menyelesaikan dan mengkomunikasikan masalah sehari-hari yang melibatkan penalaran kuantitatif. Siswa yang memiliki kemampuan matematika sedang pun mampu menyelesaikan soal dengan melibatkan penalaran kuantitatif.

Berdasarkan pembahasan profil penalaran kuantitaatif subjek perempuan dan subjek laki-laki, diperoleh profil penalaran kuantitatif siswa SMP ditinjau dari gender berdasarkan deskriptor yang telah dikaji dan ditetapkan untuk digunakan dalam penelitian ini. Untuk mengetahui profil penalaran kuantitatif siswa SMP ditinjau dari gender dibahas persamaan dan perbedaan profil penalaran kuantitatif antara subjek perempuan dan subjek lakilaki, yaitu: (1) Beberapa kali membaca soal hingga kedua subjek memahami informasi kuantitatif dan masalah yang disajikan dalam bentuk kata-kata yang terdapat dalam soal; (2) kedua subjek menyebutkan informasi dan menunjukkan pada bagian 
mana informasi tersebut didapat. Keduanya pun menyebut grafik sebagai 'diagram'; (3) kedua subjek menyebutkan hal-hal yang diketahui dalam soal dengan kata-kata sendiri secara lisan maupun tulisan dan menyatakan batasan masalah dengan benar; (4) kedua subjek menyatakan kemungkinan jawaban untuk masalah tersebut adalah ada, walaupun keduanya menggunakan pendekatan yang berbeda untuk menentukan hal tersebut; (5) kedua subjek mengkomunikasikannya secara lisan maupun tulisan dan mampu menerjemahkan jawaban soal ke konteks masalah yang awalnya jawaban berupa pernyataan atau representasi matematis dan; (6) kedua subjek mengenali keterbatan metode yang digunakan untuk menyelesaikan masalah.

Perbedaan profil penalaran kuantitatif antara subjek perempuan dan subjek lakilaki, yaitu: (1) subjek M mampu menyusun rumus berupa persamaan yang ditentukan berdasarkan hasil interpretasi subjek $M$ terhadap informasi yang diberikan secara implisit dalam soal. Sedangkan subjek F tidak menyusun atau menetukan suatu rumus apapun dari hasil interpretasi subjek F. Dan hanya subjek $M$ yang mengetahui rumus hubungan tiga kuantitas yang terdapat dalam soal; (2) dalam menginterpretasikan informasi kuantitatif:

1. Subjek M menyebutkan bahwa dalam soal akan melibatkan 3 kuantitas, sedangkan subjek $\mathrm{F}$ menyebutkan hanya terdapat 2 kuantitas.

2. Subjek M menyebutkan bahwa terdapat dua perbandingan aditif antara dua nilai dalam satu kuantitas, sedangkan subjek $\mathrm{F}$ menyebutkan hanya ada satu perbandingan aditif tersebut. Sehingga subjek $M$ menemukan lebih banyak perbandingan aditif antara dua nilai dalam satu kuantitas dalam soal dari pada subjek $F$ temukan.

3. Subjek F menyebutkan perbedaan nilai antara dua kuantitas dan hubungan antara nilai kuantitas yang diketahui dengan hal yang ditanyakan dalam soal, sedangkan subjek $M$ tidak menyebutkan hal tersebut.
(3) Subjek F dan subjek M menggunakan metode yang berbeda dalam menyelesaikan soal. Subjek F menggunakan metode geometri dengan memanfaatkan sifat kesejajaran dan perpotongan dua garis, sedangkan subjek $\mathrm{M}$ menggunakan metode aljabar dengan menyusun dan menyelesaikan persamaan linear satu variabel.

\section{PENUTUP \\ Kesimpulan}

Profil penalaran kuantitatif ditinjau dari gender adalah sebagai berikut: (1) kedua subjek memahami informasi kuantitatif dengan berbagai bentuk; (2) subjek laki-laki merumuskan persamaan dari hasil interpretasi informasi kuantitatif yang diberikan secara implisit; (3) dari hasil interpretasi, subjek perempuan menyebutkan terdapat dua kuantitas sedangkan subjek laki-laki menyebutkan terdapat tiga kuantitas yang terlibat dalam masalah soal dan keduanya menyebutkan beberapa hubungan kuantitas-kuantitas tersebut; (4) subjek perempuan menggunakan metode geometri dengan menerapkan suatu sifat, sedangkan laki-laki menggunakan metode aljabar dengan menyusun dan menyelesaikan suatu persamaan; (5) keduanya memperkirakan jawaban dan memeriksa kemasukakalannya dengan berbeda sesuai dengan metode yang digunakan; (6) keduanya mengkomunikasikan informasi kuantitatif secara lisan maupun tulisan; (7) kedua subjek mengenali keterbatasan metode yang digunakan dalam menyelesaikan soal.

\section{Saran}

1. Hasil penelitian menunjukkan bahwa ada perbedaan profil penalaran kuantitatif siswa SMP perempuan dan laki-laki. Siswa perempuan lebih mudah menganalisis informasi kuantitatif yang diberikan dalam bentuk grafik sedangkan siswa lakilaki mampu menginterpretasi informasi kuantitatif dalam bentuk kata-kata dan menggunakan hasil interpretasi tersebut untuk menyelesaikan soal. Hal ini 
memungkinkan adanya perbedaan cara menyelesaikan suatu masalah yang dapat mempengaruhi ketercapaian hasil belajar. Peneliti merekomendasikan kepada guru dan perancang pembelajaran matematika untuk memperhatikan temuan tersebut dan dapat mempertimbangkan profil tersebut dalam merancang proses pembelajaran matematika pada jenjang SMP untuk mengembangkan kemampuan penalaran kuantitatif siswa SMP ditinjau berdasarkan gender. Jika dalam proses pembelajaran kelas laki-laki dan perempuan dipisah maka soal yang informasi kuantitatif dalam bentuk kata-kata dapat digunakan di kelas laki-laki, namun di kelas perempuan informasi dalam bentuk grafik akan mempermudah siswa perempuan dalam menganalisi informasi kuantitatif untuk menyelesaiakan soal. Jika siswa laki-laki dan siswa perempuan berada dalam satu kelas, maka guru memberikan kedua bentuk penyajian informasi tersebut namun memberikan perhatian dan tanggapan yang berbeda dalam membantu siswa laki-laki dan siswa perempuan menyelesaikan suatu soal.

2. Kajian dalam penelitian ini masih terbatas pada profil penalaran kuantitatif siswa SMP ditinjau dari gender yang memiliki kemampuan matematika sedang. Oleh karena itu, dapat dilakukan penelitian lain, misalnya pada tingkat kemampuan rendah atau tinggi.

3. Soal penalaran kuantitatif yang dikembangkan dalam penelitian ini didesain untuk menganalisis profil penalaran kuantitatif siswa. Salah satunya yaitu untuk mendeskripsikan pemahaman terhadap informasi kuantitatif yang diberikan dalam berbagai bentuk yaitu dalam bentuk kata-kata, rumus, tabel dan grafik. Keempat bentuk tersebut diberikan dalam soal namun informasi yang disajikan dalam bentuk grafik, tabel dan kata-kata memberikan informasi yang sama. Sehingga, disarankan untuk mengembangkan soal dengan satu konteks masalah, namun menyajikan informasi kuantitatif yang berbeda atau memperkuat informasi kuantitatif sebelumnya.

\section{DAFTAR PUSTAKA}

Benbow, C.P dkk (2000). Sex Differences in Mathematical Reasoning Ability at Age 13. Vanderbilt University dan Iowa State University.

Davidson, $M$ dan McKinney, G. (tanpa tahun). Quantitative Reasoning: An Overview. USA: Office of Institutional Assessment and Testing, Western Washington University.

Depdiknas. (2006). Permendiknas Nomor 22 Tahun 2006 tentang Standar Isi untuk Satuan Pendidikan Dasar dan Menengah. Jakarta: BSNP.

Dwyer, C.A., Gallagher, A., Levin, J. dan Morley, M.E. (2003). What is Quantitative Reasoning? Defining the Construct for Assessment Purpose. Princeton: ETS.

Ellis, A.B. (2011). Algebra in The Middle Schools: Developing Functional Relationship Through Quantitative Reasoning.Madison, USA: School of Education, University of WisconsinMadison.

Firman, H. (2014). Diagnosing Weaknesses of Indonesian Students' Learning on The Basis of PISA 2012 Survey Results. Bandung: UPI

Geary, D.C.; Saults, S.J.; Liu,F.; dan Hoard, M.K. (2000). Sex Differences in Spatial Cognition, Computational Fluency, and Arithmetical Reasoning. University of Missouri at Columbia.

Hayat, B dan Yusuf, S. (2010). Mutu Pendidikan. Jakarta: Bumi Aksara.

Hidayati, N.N. (2013). Profile Berpikir Lateral Siswa Sekolah Menengah Kejuruan dalam Menyelesaikan Masalah Matematika Kontekstual Ditinjau dari Perbedaan Gender. Tesis. Universitas Negeri Surabaya.

Hightower, M.W. (2003). The "Boy Turn" in Research on Gender and Education. 
Jurnal Penelitian pendidikan. Madison : University of Wisconsin.

Karim, N. (2007). Quantitative Reasoning Applications and Modelling in The Real World at Zayed University. Zayed University.

Koedinger, K.R dan Nathan, M.J. (2004). Real Story Behind Story Problem: Effect of Representation on Quantitative Reasoning. New York: Lawrence Erlbaum Associate.

Krutetskii, V.A. (1976). The Psychology of Mathematical Abilities in Schoolchildren. USA: The University of Chicago.

Lakin, J.M. (2013). Sex Differences in Reasoning Abilities: Surprising Evidence that Male-Female Ratios in The Tails of The Quantitative Reasoning Distribution Have Increased. Alabama: Department of Educational Foundations, Leadership, and Technology, Auburn University.

Lobato, J dan Siebert, D. (2002). Quantitative Reasoning in a Reconceived View of Transfer. Jurnal Sikap terhadap Matematika. Amerika Serikat : Pergamon.

Madison, B. L. (2003). "The Many Faces of Quantitative Literacy." In Quantitative Literacy: Why Numeracy Matters for Schools and Colleges, edited by Bernard L. Madison and Lynn Arthur Steen. Princeton, NJ: National Council on Education and the Disciplines.

NICHE (Numeracy Infusion Course for Higher Education). (2015). Numeracy and Quantitative Reasoning. Online (http://serc.carleton.edu/NICHE/numer acy_qr.html diakses pada tanggal 14 Februari 2015 pukul 10.06).

Nur, M. (2001). Perkembangan Selama Anak-anak dan Remaja. Buku Ajar. Surabaya: UNESA PRESS

Pai'pinan, M. (2013). Profile Metakognisi Mahasiswa Calon Guru Matematika dalam Menyelesaikan Masalah Terbuka Geometri Ditinjau dari Perbedaan Gender. Tesis. Universitas Negeri Surabaya.

Smith, J. dan Thompson, P. W. (2007). Quantitative reasoning and the development of algebraic reasoning. In J. J. Kaput, D. W. Carraher \& M. L. Blanton (Eds.), Algebra in the Early Grades (h.95-132). New York: Erlbaum.

Sudarman. (2009). Proses Berpikir Siswa Climber dalam Menyelesaikan Masalah Matematika. Online. (http://jurnal.pdoo.lipi.go.id/admin/jur nal/1010919.pdf diakses tanggal 16 Desember 2014 pukul 21.50).

Stafford, R.E. (1971). Hereditary and Environmental Components of Quantitative Reasoning. New York: ERIC.

Thompson, P.W. (1990). A Theoretical Model of Quantity-Based Reasoning in Arithmetic and Algebra. Makalah disajikan pada the Annual Meeting of the American Educational Research Association, San Fransisco, tanggal 2731 Maret 1989.

-----------. (2011). Quantitative Reasoning and Mathematical Modelling. Arizona State University.

Tiang, Z. dan Huang, X. (2009). A Study Of Children's Spatial Reasoning And Quantitative Reasoning Abilities. Jurnal Pendidikan Matematika. Cina : Changshu Institute of Technology.

Wang, W. (2006). Gender Differences in Gifted Children's Spatial, Verbal, and Quantitative Reasoning Abilities in Taiwan. Jurnal. Taiwan: The Center for Special Education, Chuang Yuan Christian University.

\section{RIWAYAT HIDUP PENULIS}

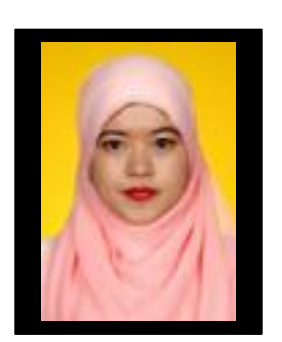

Dzikra Fu'adiah, M.Pd. Lahir di Padang, 12 April 1990. Staf pengajar di STAI Siliwangi Bandung. Studi S1 Pendidikan Matematika UIN Sunan Gunung Djati, Bandung, dan lulus tahun 2012; dan studi S2 Pendidikan Matematika Universitas Negeri Surabaya dan lulus tahun 2015. 